\title{
MENGOPTIMALKAN PERKEMBANGAN ANAK USIA DINI MELALUI KEGIATAN PARENTING.
}

\author{
Oleh: \\ I Gusti Lanang Agung Wiranata \\ Asesor Badan Akreditasi Nasional PAUD dan PNF Propinsi Bali \\ Email:jungwira14@gmail.com
}

\begin{abstract}
ABSTRAK
Orangtua yang bijaksana akan memberi pengaruh yang sangat besar terhadap pertumbuhan dan perkembangan anak. Kelak setelah dewasa, anak akan menjadi seseorang yang sangat dipengaruhi pola asuh yang diberlakukan oleh orangtuanya. Namun sayangnya masih banyak orang tua yang melakukan kesalahan dalam mendidik anaknya sehingga berdampak buruk bagi anak. Hal inidisebabkan karena kekurangpahaman dan kurangnya pengetahuan yang dimiliki oleh orang tua. Sebagai orang tua perlu dimulai kesadaran untuk mewujudkan kemandirian pada anak usia dini. Orang tua juga perlu memberikan kasih sayang yang cukup bagi anak agar anak tidak merasa kesepian. Anak-anak yang dibesarkan dalam limpahan kasih sayang orang tua akan memperlakukan orang lain dengan kasih sayang pula. Setelah dewasa, ia akan belajar mencintai istri, anak, sahabat, dan masyarakatnya. Dengan demikian, orang tua sudah membantu proses anak menjalani tugas perkembangannya sehingga akan terbentuk proses kemandirian dalam diri anak hingga dewasanya. Supaya anak mendapatkan kemandirian tersebut, maka orang tua membutuhkan pengetahuan atau ilmu tentang cara mendidik, mengasuh, dan membimbing anak dengan baik dan benar. Salah satu kegiatan yang dapat dilakukan oleh orang tua untuk menstimulasi anaknya adalah dengan mengikuti berbagai kegiatan parenting sebagai program pembimbing orang tua.
\end{abstract}

Kata Kunci: Program parenting, orang tua, pengasuhan positif, perkembangan anak.

\begin{abstract}
Parents who oppose will provide enormous growth in the growth and development of children. Later, after adults, children become who really like the parenting style imposed by their parents. However, there are still many parents who make mistakes in educating bad facts for children. This is because of the lack of understanding and knowledge possessed. As parents, awareness must be taken to realize independence in early childhood. Parents do not need to provide enough affection for children to be disliked. Children who are raised in an abundance of love for their parents will treat others with affection too. After adulthood, he will learn to love his wife, children, friends and society. Thus, parents must help the child development process so that it willdevelopof independence
\end{abstract}


in the child to his adult life. In order to get that independence, parents need knowledge or how to educate, care, and guide children properly and correctly. One of the activities that can be done by parents to stimulate heredity is to take part in various parenting activities as a parent guidance program.

Keywords: Parenting program, parents, positive parenting, and child development.

\section{PENDAHULUAN}

Manusia merupakan salah satu makhluk yang selalu bertumbuh dan berkembang. Anak usia dini adalah bagian dari manusia yang juga selalu bertumbuh dan berkembang bahkan lebih pesat dan fundamental pada awal-awal tahun kehidupannya. Kualitas perkembangan anak di masa depannya, sangat ditentukan oleh stimulasi yang diperolehnya sejakdini.

Pemberian stimulasipendidikan untuk anak usia dini adalah hal yang sangat penting mengingat $80 \%$ pertumbuhan otak berkembang pada anak sejak usia dini. Perkembangan otak anak usia dini lebih besar pada usia lahir hingga sebelum 8 tahun kehidupannya, 20\% siasanya ditentukan selama kehidupannya setelah masa kanak-kanak. Dan tentu saja bentuk stimulasi yang diberikan harusnya dengan cara yang tepat sesuai dengan tingkat perkembangan anak usia dini. Agar anak mencapai tingkat perkembangan yang optimal, dibutuhkan keterlibatan orang tua maupun orang dewasa untuk memberikan rangsangan yang bersifat menyeluruh dan terpadu yang meliputi pendidikan, pengasuhan, kesehatan, gizi, dan perlindungan yang diberikan secara konsisten.

Pada dasarnya pendidikan anak usia dini merupakan upaya dan tindakan yang dilakukan oleh pendidik/guru dan orang tua dalam proses pengasuhan, perawatan, dan pendidikan pada anak dengan menciptakan lingkungan dimana anak dapat mengeksplorasi pengalaman yang memberikan kesempatan kepadanya untuk mengetahui dan memahami pengalaman belajar yang diperoleh secara langsung dari lingkungannya.

Anak menghabiskan hari-harinya di sekolah, di rumah, dan di lingkungannya. Keberadaan anak di rumah maupun di lingkungannya mempunyai jumlah persentase terbesar yang mencapai $80 \%$, sedangkan disekolah hanya $20 \%$. Iniberarti, anak akan lebih banyak mendapatkan pembelajaran di keluarga ataupun di lingkungannya dibandingkan dengan di sekolah atau lembaga pendidikan. Jika keluarga dan lingkungan tidak dapat mendukung proses pembelajaran yang tepat bagi anak, anak akan kehilangan sebagian besar proses perkembangannya. Untuk itu, orang tua harus mengetahui proses pembelajaran yang tepat dan cocok sesuai dengan perkembangan anaknya, supaya proses pembelajaran di sekolah dan dirumah bisa berkelanjutan dan berkesinambungan. Oleh karena itu, salah satu kegiatan yang dapat dilakukan oleh orang tua untuk menstimulasi anaknya adalah dengan mengikuti kegiatan parenting sebagai program pembimbing orangtua.

\section{PEMBAHASAN}

\section{A. Anak Usia Dini.}

Menurut NAEYC (National Association

Educational Young Children) anak usia dini 
merupakan sosok individu yang sedang menjalani suatu proses perkembangan dengan pesat dan fundamental bagi kehidupan selanjutnya, menurut $N A E Y C$ anak usia dini berada pada rentang usia 0-8 tahun. Sedangkan anak usia dini menurut Undang-undang Nomor 20 tahun 2003 tentang Sistem Pendidikan Nasional disebutkan bahwa mereka adalah anak yang berada pada rentang usia sejak lahir sampai dengan enam tahun (Direktorat Pendidikan Anak Usia Dini, 2010: 3), dan jika disesuaikan dengan pendapat internasional, maka anak usia dini di Indonesia adalah mereka yang sejak lahir hingga memasuki jenjang SD kelas awal.

Usia dini merupakan masa keemasan (golden age), oleh karena itu pendidikan pada masa ini merupakan pendidikan yang sangat fundamental dan sangat menentukan perkembangan anak selanjutnya. Pada periode ini hampir seluruh potensi anak mengalami masa peka untuk tumbuh dan berkembang secara cepat. Pada masa ini anak sangat membutuhkan stimulasi dan rangsangan dari lingkungannya. Apabila anak mendapatkan stimulus yang baik, maka seluruh aspek perkembangan anak akan berkembang secara optimal.

Pendidikan adalah suatu upaya untuk membantu memanusiakan manusia. Artinya, melalui proses pendidikan diharapkan terlahir manusia-manusia yang lebih baik. Anak sebagai makhluk individu dan sosial, sangat berhak untuk mendapatkan pendidikan yang sesuai dengan kebutuhan dan kemampuannya. Dengan pendidikan yang diberikan, diharapkan anak dapat tumbuh cerdas sesuai dengan potensi yang dimilikinya, sehingga kelak dapat menjadi anak bangsa yang berkualitas. Melalui pendidikan yang dibangun atas semangat Bhineka Tunggal Ika, diharapkan bangsa Indonesia dapat menjadi bangsa yang tahu akan hak dan kewajibannya untuk hidup berdampingan, tolong-menolong dan saling menghargai dalam sebuah harmoni sebagai bangsa yang bermartabat.

Jalur pendidikan anak usia dini terdiri atas pendidikan formal, pendidikan nonformal, dan pendidikan informal. Jalur formal meliputiTaman Kanak-kanak (TK) dan Raudatul Athfal (RA), jalur nonformal meliputi Kelompok Bermain

(KB), Tempat Penitipan Anak (TPA) dan Satuan Paud Sejenis(SPS), sedangkan pendidikan informal adalah jalur pendidikan keluarga dan lingkungan. Secara umum tujuan pendidikan anak usia dini adalah untuk mengembangkan dan menstimulasi berbagai potensi anak sejak dini sebagai persiapan untuk memasuki jenjang pendidikan berikutnya dan mampu menyesuaikandiridenganlingkungannya.

Pendidikan anak usia dini merupakan jenjang pendidikan sebelum jenjang pendidikan dasar yang merupakan suatu upaya pembinaan yang ditujukan bagi anak sejak lahir sampai dengan usia enamtahun yang dilakukan melalui pemberian rangsangan pendidikan untuk membantu pertumbuhan dan perkembangan jasmani serta rohaniagar anak memilikikesiapan dalammemasukipendidikanlebih lanjut (Hasan, 2012:15). Oleh karena anak merupakan pribadi yang unik dan melewati berbagai tahap perkembangan, maka lingkungan yang diupayakan oleh pendidik dan orang tua hendaknya memperhatikankeunikan anak-anak dan disesuaikan dengan tahap perkembangan anak.

\section{B. Perkembangan Anak Usia Dini.}

Menurut David Shaffer (Suryana, 2016: 35) perkembangan adalah perubahan yang kontinyu dan sistematis dalam diri seseorang sejak tahap 
konsepsi sampai meninggal dunia. Anak mengalami proses perkembangan dimulai sejak dari dalam kandungan, masa bayi, balita, usia sekolah dan remaja. Setiap tahapan proses perkembangan mempunyai ciri khas tersendiri. Perkembangan anak usia dini meliputi beberapa aspek diantaranya aspek pertumbuhan fisik dan perkembangan motorik, aspek perkembangan kognitif, aspek perkembangan sosio emosional, aspek perkembangan bahasa, aspek perkembangan moral agama, serta aspek perkembangan seni. Perkembangan seluruh aspek-aspek tersebut secara menyeluruh dan berkesinambungan menjadisuatu halyang sangat berarti. Dalam memberikan stimulasi untuk mengembangkan aspek-aspek tersebut, tentulah pemahaman akan konsep dasar berkaitan dengan hal tersebut sangat diperlukan.

Perkembangan merupakan suatu perubahan yang berlangsung seumur hidup dengan bertambahnya struktur dan fungsi tubuh yang lebih kompleks dalam kemampuan gerak kasar, gerak halus, bicara, bahasa, sosialisasi dan kemandirian. Ciri-ciri pertumbuhan dan perkembangan anak antara lain, menimbulkan perubahan, berkorelasi dengan pertumbuhan, memiliki tahap-tahap yang berurutan dan mempunyai pola yang tetap. Selain itu menurut Soetjiningsih (1995:1) perkembangan anak usia dini merupakan bertambahnya kemampuan (skill) dalamstruktur dan fungsitubuh yang lebih komplek dalam pola yang teratur dan dapat diramalkan, sebagai hasil dari proses pematangan, menyangkut adanya proses diferensiasi dari sel-sel tubuh, jaringan tubuh, organ-organ dan sistemorgan yang berkembang sedemikian rupa sehingga masing-masing dapat memenuhifungsinya. Sedangkan menurut Oemar Hamalik (Susanto, 2011: 19), perkembangan merujuk kepada perubahan yang progresif dalam organisme bukan saja perubahan dalam segi fisik (jasmaniah) melainkan juga dalam segi fungsi, misalnya kekuatan dan koordinasi.

Banyaknya faktor yang mempengaruhi proses perkembangan anak, sehingga perkembangan seorang individu tersebut mengalami perubahan yang kompleks. Mulai dari unsur-unsur bawaan hingga unsur-unsur pengalaman yang diperoleh langsung dalam berinteraksi dengan lingkungannya, sama-sama memberikan kontribusi tertentu terhadap arah dan laju perkembangan anak tersebut. Seorang bayi dari hari ke hari akan mengalami perkembangan baik fisik maupun psikologis, namun tentunya tiap anak tidak sama persis pencapaiannya, ada yang cepat ada pula yang membutuhkan waktu agak lama. Untuk membantu perkembangannya ibu dapat membantu memberikan stimulasi yang disesuaikan dengan keunikan masing-masing anak.

Perkembangan anak perlu diperhatikan sejak dini agar mampu mengimbangi aktivitas anak dalam memperoleh pendidikannya secara maksimal. Menurut Yusuf Syamsu (Susanto, 2011: 19), perkembangan adalah perubahanperubahan yang dialami oleh individu atau organisme menuju tingkat kedewasaannya atau kematangannya (maturation) yang berlangsung secara sistematis, progresif dan berkesinambungan, baik menyangkut fisik (jasmaniah) maupun psikis (rohaniah).

Pentingnnya pertumbuhan dan perkembangan anak usia dini tidak terlepas kaitannya dengan perkembangan struktur otak dan kecerdasan. Menurut Wittrock (Suyadi, 2010:11) ada tiga wilayah perkembangan otak yang mengalami peningkatan pesat, yaitu 
pertumbuhan serabut dendrit, kompleksitas hubungan sinapsis, dan pembagian sel saraf. Ketiga wilayah otak tersebut sangat penting untuk dikembangkan sejak usia dini. Karena pada saat lahir otak anak memiliki sekitar 100 milyar hingga 200 milyar sel saraf. Setiap sel saraf siap berkembang sampai taraf tertinggi dari kapasitas manusia jika mendapat stimulasi yang sesuai dengan lingkungannya. Pada fase perkembangan ini, anak akan memiliki potensi besar dalam mengembangkan kemampuan berbahasa, matematika, keterampilan berpikir, dan pembentukan stabilitas emosional. Maka tidak salah jika dikatakan bahwa anak usia dini merupakan masa keemasan atau golden age.

Menurut Direktorat Pendidikan Anak Usia Dini (2006: 5) pada hakekatnya ada beberapa prinsip perkembangan anak, yaitu sebagai berikut:

a) Anak akan belajar dengan baik apabila kebutuhan fisiknya terpenuhi, serta merasa aman dan nyaman dalam lingkungannya.

b) Anak belajar melalui interaksi sosial, baik dengan orang dewasa maupun teman sebayanya.

c) Minat dan ketekunan anak akan memotivasi belajar anak.

d) Perkembangan dan gaya belajar anak harus dipertimbangkan sebagai perbedaan individu.

e) Anak belajar secara terus menerus, dimulai dari membangun pemahaman tentang sesuatu, mengeksplorasi lingkungan, dan menemukan kembali suatu konsep.

f) Anak belajar dari hal-hal yang sederhana sampai yang kompleks dan dari yang konkret ke abstrak.

\section{Kegiatan Parenting.}

Program parenting adalah program pendidikan yang diberikan kepada orang tua agar pengetahuan yang dimiliki orang tua menjadi bertambah tentang tumbuh kembang anak serta agar pendidikan yang diperoleh anak selaras antara di rumah dan di sekolah. Menurut Helmawati (2015: 60) parenting merupakan suatu proses interaksiyang berkelanjutan antara orang tua dan anak-anak mereka yang meliputi berbagai aktivitas seperti memberi makan (nourishing), memberi petunjuk (guiding), dan melindung (protecting) anak-anak ketika mereka tumbuh berkembang. Selain itu, parenting juga merupakan ilmu yang sangat penting untuk diketahui oleh para orang tua maupun calon orang tua tentang cara mendidik, mengasuh, dan membimbing anak dengan benar dan tepat.

Pendidikan orang tua yang dimaksud bukanlah pendidikan formal yang dijalani oleh orang tua, namun yang dimaksud di sini adalah pendidikan yang diberikan kepada orang tua dalam rangka untuk mengetahui dan mengaplikasikan pendidikan yang tepat dalam mendidik anak usia dini, terutama saat anak berada dalam lingkungan keluarga bersama orangtuanya dirumah.

Tujuan dari penyelenggaraan program parenting adalah mengajak para orang tua untuk memberikan yang terbaik untuk anakanaknya. Karena setiap orang tua pasti menginginkan anak-anaknya tumbuh dengan sempurna. Sedangkan menurut Latifdkk, (2013: 261) tujuan parenting adalah untuk membangun pikiran orang tua, sehingga dia mampu membangun anaknya, karena keberadaan anaknya lebih banyak menghabiskan waktu di 
rumah maupun di lingkungannya daripada di sekolah atau di lembaga pendidikan. Menurut Helmawati (2015: 61) secara khusus tujuan pengembangan program parenting adalah sebagaiberikut:

a) Meningkatkan keterampilan dan pengetahuan orang tua dalam melaksanakan pengasuhan, perawatan, dan pendidikan anak di dalam keluarga sendiri.

b) Mempertemukan keinginandan kepentingan antara pihak sekolah dan orang tua, guna menyingkronkan keduanya sehingga pendidikan yang dikembangkan di lembaga PAUD dapat ditindaklanjuti di lingkungan keluarga.

c) Menghubungkan antara program sekolah dan program rumah, sehingga terjalin keselarasan dan keterkaitan, kerja sama yang saling mendukung dan saling mengutkan.

Program parenting yang diberikan pada orang tua akan mempengaruhi pola asuh orang tua terhadap anak. Pola asuh orang tua adalah pola perilaku yang diterapkan orang tua pada anak dan bersifat relatif konsisten dari waktu ke waktu. Pola asuh adalah suatu cara terbaik yang dapat ditempuh orang tua dalam mendidik anak-anaknya sebagai perwujudan dari rasa tanggung jawab kepada anak-anaknya (Mansur, 2005: 350). Pola asuh juga berarti upaya orang tua yang konsisten dan persisten dalam menjaga dan membimbing anak sejak dilahirkan hingga remaja (Djamarah, 2014: 51). Sedangkan menurut Santoso (2011: 179) pola asuh adalah cara pendekatan orang dewasa kepada anak dalam memberikanbimbingan, arahan, pengaruh dan pendidikan supaya anak menjadi dewasa dan mampu berdiri sendiri.
Pengetahuan dan pemahaman orangtua dalam pola asuh terhadap anak sangat berpengaruh terhadap tumbuh perkembangan anak dan masa depannya. Maka dariitu orangtua perlu diberikan keterampilan dalam mendidik anak didalam keluarga sepaya anak dapat menjadi sumber daya manusia yang berkualitas di masa yang akan datang.

Adapun manfaat kegiatatan parenting, yaitu dapat membangun komunikasi yang baik antara lembaga pendidikan dengan orangtua. Sehingga pola pengasuhan yang dijalankan di lembaga dengan yang diterapkan orang tua dirumah menjadi selaras, melalui kegiatan parenting orangtua juga dapat mengetahui capaian perkembangan anak, hak-hak dasar apa saja yang harus dipenuhi orangtua dalam kelangsungan hidup anak, dan memberikan pengetahuan kepada orangtua. Selain itu, menurut Ariyati (2016) ada beberapa manfaat dalam pelaksanaan parenting yaitu sebagai berikut:

a) Terjalinnya mitra kerja lintas sektor, misalnya dari pengusaha-pengusaha yang berkaitan dengan kebutuhan tumbuh kembang anak, instansi pemerintah, penerbit buku, dan lainlain,

b) Terpenuhinya kebutuhan hak-hak anak,

c) Berkembangnya rasa percaya diri orang tua dalam mendidikanak,

d) Terjalinnya hubungan yang harmonis pada masing-masing anggota keluarga sesuai dengan tugasnyamasing-masing,

e) Terciptanya hubungan antar keluarga di lingkungan masyarakat sekitar lembaga pendidikan, dan

f) Terjalinnya mitra kerja antar sesama anggota parenting. 
Dalam melaksanakan kegiatan parenting adapun langkah-langkah yang dapat dilakukan menurut Helmawati (2015: 61) yaitu sebagai berikut:

a) Melakukan Identifikasi Kebutuhan Orang Tua, yaitu mengidentifikasi kebutuhan orang tua yang beragam, karena setiap orang tua memiliki kebutuhan dan keinginan yang berbeda-beda, ada orang tua yang ingin anaknya bisa cepat membaca dan menghitung, ada orang tua yang ingin anaknya pandai menyanyi dan menari, ada orang tua yang ingin anaknya lebih mandiri, dan lain-lain.

b) Membentuk Kepanitiaan Parenting yang Melibatkan Komite Sekolah, yaitu kepanitiaan program parenting harus dibuat dengan jelas dan melibatkan komite sekolah, sehingga program yang akan dikembangkan betul- betul dapat menjembatani kebutuhan orang tua dan kebutuhan sekolah.

c) Membuat Job Deskripsi Masing-masing Bagian, yaitu setelah susunan kepanitian terbentuk, selanjutnya membuat rencana tugas atau job deskripsi untuk masingmasing bidang.

d) Menyusun Program, yaitu kepanitian yang sudah terbentuk selanjutnya membuat program yang akan dilaksanakan, siapa pelaksananya, siapa narasumbernya, anggarannya dan sebagainya di bawah komando ketua program.

e) Menyusun JadwalKegiatan, yaitu menyusun jadwal program secara terperinci dan jelas, mulaidaritempatnya, waktunya, pesertanya dan sebagainya.

f) Menidentifikasi Potensi dan Mitra Pendukung, yaitu menjalin kemitraan dengan berbagai kalangan, seperti dokter dan petugas kesehatan, puskesmas, praktisi PAUD, instansipemerintah maupun swasta, tokoh masyarakat dan sebagainya.

g) Melaksanakan Program Sesuai dengan Agenda, yaitu menjalankan program sesuai dengan jadwal yang telah dibuat.

h) Melakukan Evaluasi dan Kesepakatan Bersama, yaitu melakukan evaluasi setiap selesai melaksanakan program, untuk mengetahui dimana kekurangan atau kelemahan sehingga bisa diperbaiki diprogram berikutnya.

Menurut Ariyati (2016) ada beberapa jenis program parenting yang dapat dilaksanakan dalam kegiatan dilembaga PAUD yaitu:

a) Think-thank atau sumbang saran yaitu mengeluarkan pendapat dan diskusi tentang pembelajaran yang paling tepat bagi anak usia dini misalnya pembelajaran tematik, setiap anggota dapat menyampaikan gagasan-gagasan atau permasalahanpermasalahan yang ada sekaligus melakukan pembahasannya.

b) Arisan bicara, yaitu setiap anggota, secara undian bergilir menjadi pembicara untuk menyiapkan gagasan sesuaitopik yang telah ditentukan.

c) Seminar, mengundang narasumber dan sponsor.

d) Praktek keterampilan, misalnya membuat alat permainan edukatif, memasak makanan bergizi untuk anak, dan sebagainya.

e) Outbond, yakni kegiatan di luar ruangan yang dilakukan secara bersama-sama oleh semua anggota keluarga, yang disispkan kegiatan diskusi atau praktek permainan- 
permainan yang dapat dilakukan oleh anggota keluarga secara bersama-sama.

f) Kunjungan lapangan, yaitu kegiatan kunjungan ke tempat-tempat khusus yang bersifat mendidik misalnya ke museum, perpustakaan umum, panti asuhan, panti jompo, ke kebun atau pertanian, dan sebagainya.

Kegiatan parenting akan lebih bermakna jika lembaga PAUD dapat menyusun suatu kegiatan sehingga kegiatan kumpul-kumpul dengan orangtua lebih bermakna. Menurut Helmawati (2015: 63) ada beberapa jenis bentuk- bentuk kegiatan program parenting diantaranya:

a) Parents Gathering yaitu pertemuan antara orang tua dan pihak sekolah untuk membicarakan program-program bimbingan dan pengasuhan anak dalam rangka menumbuh kembangkan anak secara optimal.

b) Foundation Class yaitu pembelajaran anak bersama orang tua di minggu-minggu pertama anak masuk sekolah atau awal tahun ajaranbaru).

c) Seminar yaitu mengundang tokoh-tokoh atau praktisi PAUD sebagai narasumber dalam kegiatanseminar.

d) Hari Konsultasi yaitu hari konsultasi untuk orang tua siswa yang dibuka oleh lembaga PAUD.

e) Field Trip yaitu kegiatan kunjungan yang dilakukan bersama orang tua ke tempattempat yang menunjang pembelajaran PAUD. Seperti museum, kebun binatang, perpustakaan, danlain-lain.

f) Home Activities yaitu kegiatan atau aktivitas di rumah dibawa ke sekolah. g) Cooking on the Spot yaitu kegiatan anakanak memasak dan menyajikan makanan bersama orang tua dengan bimbingan guru.

h) Bazar Day yaitu menyelenggarakan bazar di lembaga PAUD. Anak-anak menampilkan karyanya yang dijual kepada orang tua atau umum.

i) Mini Zoo yaitu kebun binatang mini, anakanak membawa binatang kesayangannya atau peliharaannya dari rumah ke lembaga PAUD.

j) Home Education Video yaitu merekam dan mengirim kegiatan pembelajaran anak-anak di lembaga PAUD kepada orang tua dalam bentuk $\mathrm{CD}$, agar dapat dipelajari oleh orang tua dirumah.

\section{PENUTUP}

Keluarga merupakan sebuah institusi yang paling penting dalam menciptakan dasar pendidikan dan perkembangan bagi anak. Karena pembentukan seorang anak sangat dipengaruhi oleh lingkungan terkecil yaitu keluarga. Pendidik yang pertama adalah orang tua, karena orangtualah yang pertama kali melakukan kegiatan pendidikan untuk memberikan pengaruh positif maupun negatif kepada anak bahkan semenjak anak dalam kandungan.

Program pendidikan untuk anak usia dini bersifat holistik dan terintegrasi, oleh sebab itu keterlibatan orang tua di sekolah dapat meningkatkan lingkungan belajar yang sehat dan konsisten, karena antara keluarga dan sekolah memiliki tujuan yang sama. Fakta membuktikan bahwa orang tua sedikit memiliki pengetahuan dan keterampilan dalam melaksanakan 
pengasuhan, perawatan, pendidikan, dan perlindungan, sehingga tumbuh kembang anak kurang optimal.

Dengan adanya persiapan, kita dapat menyusun kegiatan parenting agar dapat berjalan dengan lancar, dan meminimalisir adanya hambatan yang akan terjadi. Keterlibatan orangtua dalam pelaksanaan kegiatan ini sangatlah diperlukan, karena tanpa adanya orangtua maka kegiatan ini tidak akan berjalan dengan lancar. Materi yang disiapkan oleh narasumber juga disesuaikan dengan kebutuhan yang diperlukan oleh orangtua, sehingga orangtua akan aktif dalam bertanya dan berpartisipasi dalamkegiatan parenting ini.

Oleh karena itu, program parenting ini diharapkan mampu membuat orang tua dan lingkungan sekeliling anak memiliki kemampuan untuk melaksanakan fungsisosialdan pendidikan dalam hal mengasuh, merawat, mendidik, dan melindungianaknya sehingga anak dapat tumbuh dan berkembang secara optimal, sesuai dengan usia dan tahap perkembangannya.

\section{DAFTAR PUSTAKA}

Ariyati, Tatik. Jurnal Ilmiah Kependidikan. Parenting di Paud sebagai Upaya Pendukung Tumbuh Kembang Anak Usia Dini. Universitas Muhammadiyah Purwokerto: Program Studi Pendidikan Anak Usia Dini FKIP. 2016.

Direktorat Pendidikan Anak Usia Dini. Pedoman Penerapan Pendekatan "Beyond Centers And Circle Time (BCCT) dalam Pendidikan Anak Usia Dini. Jakarta. 2006.
Direktorat Pendidikan Anak Usia Dini. Peraturan Menteri Pendidikan Nasional Tentang Standar Pendidikan Anak Usia Dini. Jakarta. 2010.

Djamarah, Syaiful Bahri. Pola Asuh Orang Tua dan Komunikasi dalam Keluarga. Jakarta:Rineka Cipta. 2014.

Hasan, Maimunah. Pendidikan Anak Usia Dini. Jogjakarta: Diva Press. 2012.

Helmawati. Mengenal dan Memahami PAUD. Bandung: PT Remaja Rosdakarya. 2015.

Latif, Mukhtar, dkk. Orientasi Baru Pendidikan Anak Usia Dini. Teori dan Aplikasi. Jakarta: Kencana. 2013.

Mansur. Pendidikan Anak Usia Dini dalam Islam. Yogyakarta: Pustaka Belajar. 2005.

Santoso, Soegeng. Konsep Pendidikan Anak Usia Dini. Menurut Pendirinya 2. Jakarta: Universitas Negri Jakarta. 2011.

Soetjiningsih. Tumbuh-Kembang Anak. Jakarta: IKAPI. 1995.

Suryana, Dadan. Pendidikan Anak Usia Dini. Stimulasi dan Aspek Perkembangan Anak. Jakarta: Kencana. 2016.

Susanto, Ahmad. Perkembangan Anak Usia Dini. Jakarta: Kencana. 2011.

Suyadi. Psikologi Belajar: Pendidikan Anak Usia Dini. Yogyakarta: Pedagogia. 2010. 